\title{
Perceptions of English Education Program Students towards the Profesionalism of English Education Lecturers in Online Learning
}

Mujahidah $^{1}$, Nur Afiah ${ }^{2} \&$ Syaiful $^{3}$

1,3 Institut Agama Islam Negeri (IAIN)Parepare, Indonesia \& ${ }^{2}$ Institut Agama Islam DDI Polewali Mandar, Indonesia

\begin{tabular}{l}
\hline \hline ARTICLE INFO \\
\hline \hline Article history: \\
Received Aug 15, 2020 \\
Revised Sept 10, 2020 \\
Accepted Sept 19, 2020 \\
\hline
\end{tabular}

Keywords:

Perception,

Professionalism,

Online Learning,

English Education,

\begin{abstract}
Perception can be interpreted as a process of giving meaning to a phenomenon, event or object. professionalism is interpreted as a professional trait. Those traits are mastering the Science in their field and have high skills in carrying out their duties. This Study aimed to describe the students' perceptions of professionalism lecturer English Education Program, State Islamic Institute of Parepare. To achieve this goal a questionnaire was distributed to 50 students $(40 \%$ of the population). This Research is a descriptive quantitative study with a survey approach. The data processed using simple tabulation techniques and the data qualitatively interpreted. There are five aspects of the professionalism observed, namely: the ability to speak English, online teaching skills, insights, timeliness and using of online learning application. By the results of data analysis found that, the lecturers of English Education Program, State Islamic Institute of Parepare has a high level of professionalism.
\end{abstract}

\section{Clonflict of Interest:}

None

Funding:

None

Corresponding Author: Mujahidah, IAIN Parepare. E-mail: mujahidah@iainpare.ac.id.

\section{Introduction}

This Research is backed by some of the following: 1) The emergence of a Coronavirus Disease (Covid-19) outbreak that caused all educational activities to become stunted, one of which was a face-to-hand meeting between lecturers and students that had to be transferred into online learning. 2) One of the services to the students is that there are lecturers who are qualified in other sense professionals. Broadly, professional means having a commitment to work, having a strong competency, a broad insight, etc. 3) in educational institutions, the student satisfaction is measured based on the student's perception or opinion on the quality of service provided by the institution. Similarly, in IAIN Parepare, one of the benchmarks for the satisfaction of the service to the students is the perception of the services provided by the institution, especially the lecturers who come face to face with the students. To date, especially in the English language Education Department, there has been no data on the students' perception of lecturers' professionalism in Online-based learning.

The problem in this research is formulated as follows: How is the student's perception on the professionalism of English education lecturers IAIN Parepare in implementing online based learning? Specifically, the problem of this research will be formulated as follows:

This research aims to describe the student's perception of the professionalism of English education lecturers in implementing Online - based learning at IAIN Parepare. 
The results of this research are expected to be beneficial to: 1) English education program, Faculty of Tarbiyah and IAIN Parepare to jointly step in the policy of improving the quality of service, especially the academic service. 2) Lecturers, especially the lecturers of English Education IAIN Parepare to conduct introspection and further increase their professionalism.

In the title of this study there are three keywords: student perception, lecturer professionalism, and Online based learning. For researchers and readers to have a common perception. The following is given the boundaries:

\section{a. Students Perception}

In the title of this study, perception is interpreted as a response, opinion, or opinion. Meanwhile, students are students of English education program IAIN Parepare of 2018 generation. Therefore, student perception is the response, or opinion, of English education students IAIN Parepare of the 2018 generation.

\section{b. Lecturer Professionalism}

In the title of this study, professionalism is defined as professionalism, such as English language skills, teaching skills through online learning, broad insight, timeliness, or ability to use online learning applications. Meanwhile, the lecturer is a lecturer in English language education in IAIN Parepare. So, the professionalism of lecturers is the professional properties of the lecturers English language education IAIN Parepare. This professionalism is grouped into 5 categories, namely: very high, high, medium, low, and very low.

\section{c. Online Learning}

In the tittle of this study, Online learning means an education that take a place on internet.

\section{Literature Review}

\subsection{Definition of perception}

Perception can be interpreted as a process of giving meaning to a phenomenon, event or object. For example, how does a person's perception of a fire event. Perhaps, a person gives a perception of this event as a calamity. Others apply it as a blessing. Many experts have made a definition of perception. In general, these definitions are not much different.

Leavitt (1978) in Faradina (2007) says that perception has a narrow sense and a broad understanding. According to the narrow sense, perception is vision: how one sees something. According to the broad sense, perception is a view or understanding: How one looks or implies something.

Stephen P. Robbins (2005) defines perception; A process by which individuals organize and interpret their sensory impressions in order to give meaning to their environment, perception as a process pursued by individuals to organize and interpret or interpret the impressions of their senses in order to give meaning to their environment.

Kinicki and Kreitner (2003:67) The sense of perception as follows. Perception is a cognitive process that enables us to interpret and understand our surroundings.

Mc Shane and Von Glinow (2000:166) argue that Perception is the process of receiving information about and taking sense of our environment.

Schermerhorn, Hunt. Osborn (2005:100) Perception the process which people Select, organize, interpret, retrieve and respond to information from the world around them. In other words the perception relates to how one can interpret and respond to information originating from the outside.

\subsection{Factors Influencing Perception.}

Perception is not just forming. There are several things that can affect the formation of perception.

Robins (2005) outlines the factors that influence in interpreting the effects of the senses into a perception, there are three factors, namely:

c. factors of personal characteristics or such as the conception; attitudes, motives, interests, experiences, and expectations.

b. Situational factors such as: Time, event/ workplace, social condition.

c. factors in such targets; Things that are new, movement, sound, sound, size, background, closeness and similarity. 
Meanwhile, David Krech (1962) in Prasilika (2007:14) says The Factors That Affect The Formation of Perception are:

a. Frame of Reference, which is the framework of knowledge that someone has through education, training, reading, and others.

b. Frame of experience, a skeleton experience that is owned by someone who is usually associated with the environment.

\subsection{Professionalism}

Professionalism is interpreted as a professional trait. Those traits are Mastering the Science in their field and have high skills in carrying out their duties.

In the legislation mentioned that teachers and lecturers are required to have four competencies, namely: pedagogic competence, professional competence, social competence and personality Competence. Meanwhile, in various literature mentioned that Someone who is professional is someone who has competence.

In line with the above sense, in this research lecturer's professionalism is seen from the 5 aspects of English language skills, teaching skills, extensive insight, timeliness, and ability to use online learning applications.

a. English Ability

As a lecturer in English, this ability must be owned because the lecturer will be an example for his students. In this case, if the lecturer has poor English skills then the input to the student will be minimal.

b. Online Teaching skills

Teaching skills are also substantial for lecturers because one aspect of student success in learning is how the lecturers deliver the material in the lecture.

c. Insights

Lecturers must have a broad insight because a knowledgeable lecturer Gets a good appreciation from the students. In addition, there are many positive things students will get when lecturers have extensive insight.. When lecturers have extensive insight, students can have extensive insight as well.

d. Timeliness

In the workplace, the commitment to do the work in this is timely in teaching is very necessary because with the commitment of a lecturer can achieve good performance. In addition, lecturers will feel more accountable for their work.

e. Mastery of online learning apps

In conducting Online-based learning, one of the most important aspects is the ability to use learning applications. In addition to teaching skills, this ability also supports the success of a lecturer in providing learning.

\section{Method}

This Research is a descriptive quantitative study with a survey approach. The population of the study is all IA IN Parepare English education students of 2018 generation. Then samples were taken as much as $40 \%$ of the total number of English education students of 2018 generation selected randomly.

To obtain the data, the researcher uses questionnaire which contains several statements about the professional ism of lecturers designed by researchers.

The Collected data will be presented in a table Form. Furthermore, the data in this table will be qualitatively $\mathrm{i}$ nterpreted.

The Purpose of this research is to describe the student's perception of the professionalism of English languag e education Lecturers in implementing Online - based learning at IAIN Parepare. Questionnaire research was disseminated to 50 people or $40 \%$ of English education students of 2018 generation. There are 5 aspects that are parameters to assess the professionalism of the English Education lecturer at IAIN Parepare. As for the fi ve aspects are, English skills, Teaching skills, extensive insight, timeliness, and ability to use online learning applications.

The assessment on this study uses the highest scale number 5 and the lowest number 1 at scale. The assessme nt categories are as follows: 1). Very high with a score of 4,1-5 2). High with a score of 3,1-4, 3). Medium wi th a score of 2,1-3,4). Low with a score of 1,1-2, and 5). Very low with a score of $0,01-1$. The result of the $q$ uestionnaire analyzed by using Google form application

\section{Results and Discussion}


Research Finding

Based on five aspects of lecturers profesionalism of English education at IAIN Parepare, the research findings are as follows:

1.English Ability of English Lecturers IAIN Parepare

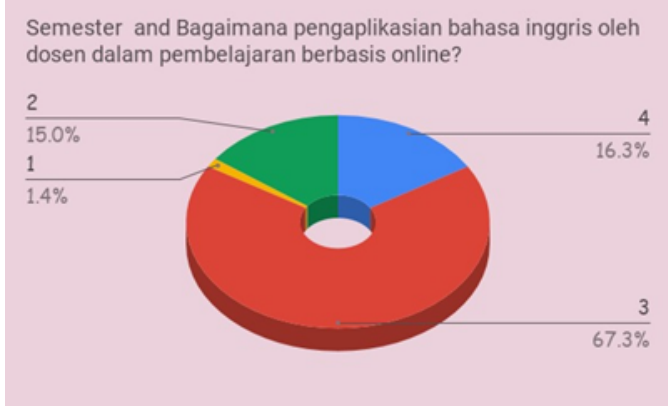

Based on the chart above, it can be seen that there are $1.4 \%$ of students who choose number 1 , meaning that applying English by lecturers in online based learning is still very low. Furthermore, there are $15.0 \%$ of students who choose number 2, meaning that applying English by lecturers in online based learning is still low. Then there are $67.3 \%$ of students who choose number 3, meaning that applying English by a lecturer in online based learning is still being. And lastly, there are $16.3 \%$ of students who choose number 4 , meaning that applying English by lecturers in online based learning is high. So that from the results of the analysis can be concluded that most students judge that applying English by a lecturer in online-based learning is still being seen from the percentage of students who chose the number 3 , which is $67.3 \%$ of students.

\section{Lecturers' Teaching Skills on Online-Based Learning}

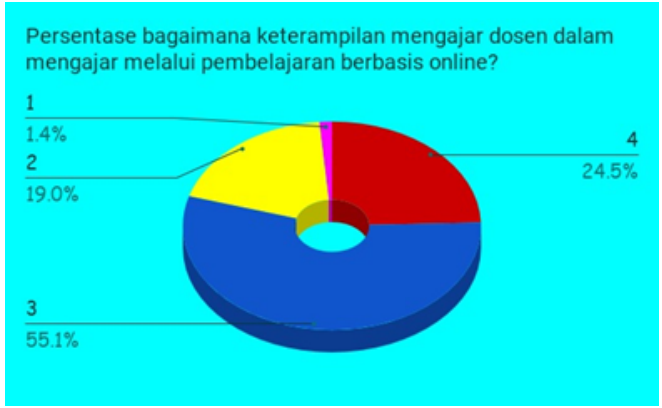

According to the chart above, it can be seen that there are $1.4 \%$ of students who choose number 1 , meaning that students' perception of teaching skills through online learning is still very low. Then, there are $19.0 \%$ of students who choose number 2 which are categorized still low, and $55.1 \%$ of students choose number 3 , it means that student perception about teaching skills of lecturers through online learning is categorized adequately (medium). Then there are $24.5 \%$ of students who choose number 4 . It means students' perception of lecturers' teaching skills can be categorized high. The above analysis can be concluded that the English education lecturers of IAIN Parepare is categorized as medium. It was seen from $55.1 \%$ of students who categorize the lecturers' teaching skills in the medium category.

\section{The Insight of English Education Lecturers of IAIN Parepare}

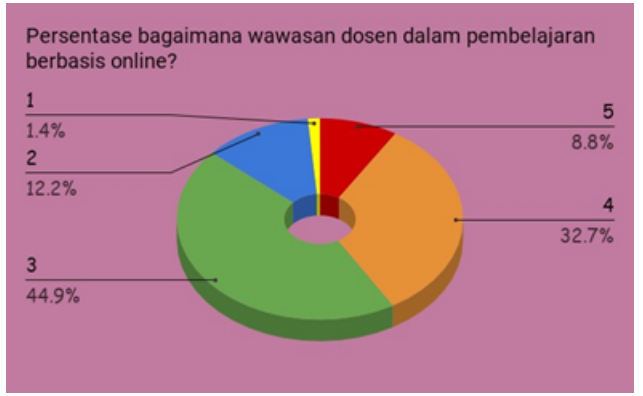


Based on the chart above, it can be seen that there are 1.4\% of English students who choose number 1, which means that lecturer insight in online learning is still very low. Then, there are $12.2 \%$ of students who choose number 2, meaning that lecturers ' insight in online barbase learning is still quite low. Furthermore, there are $44.9 \%$ of English students who choose number 3, which means that lecturer insight in online barbase learning is still moderate (medium). Furthermore, there are $32.7 \%$ of students who choose number 4 , meaning that the lecturer's insight into online barbase learning is quite high. And lastly there is a $8.8 \%$ that selects the number 5 , meaning that the lecturer insight in online barbase learning is very high. From the analysis, it can be concluded that most of the students screed that the lecturer insight in online learning is still medium. It's shown by the percentage of students who chose the number 3 as much as $44.9 \%$.

\section{The Timeliness of English Education Lecturers on Online-Based Learning}

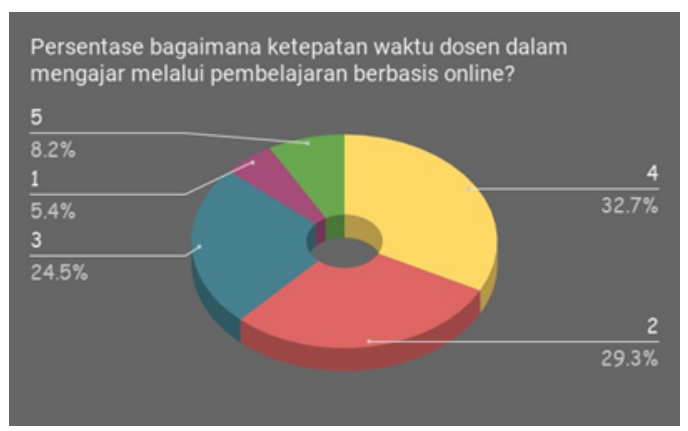

The above chart shows that as many as $5.4 \%$ of students choose number 1 , that means students assess the timeliness of lecturers in online teaching very low. While $29.3 \%$ of students who choose number 2 which means timeliness of lecturers is still in low category. Furthermore, $24.5 \%$ of students who assess the timing of lecturers are good enough. Then there are $32.7 \%$ of students who choose number 4 which means the timing of lecturers in teaching is in high category, and $8.2 \%$ of students who choose number 5 which means very high. From the above analysis it can be concluded that the timeliness of English education lecturers in online teaching can be categorized as high.

5. Mastery of Online Learning Applications

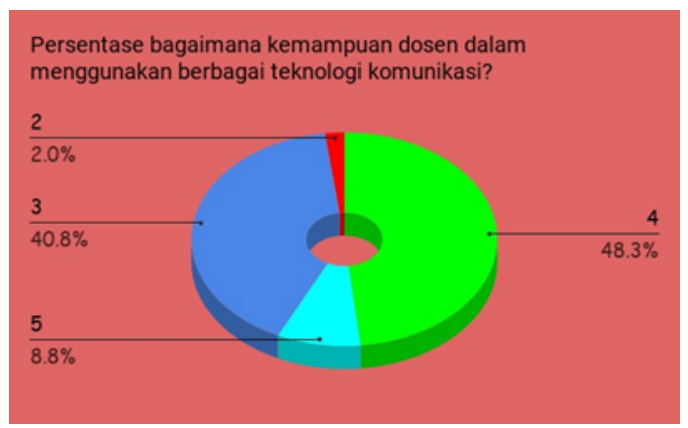

Based on the chart above, it can be seen that there are $2.0 \%$ of students who choose number 2 , meaning that the ability of lecturers in using various communication technologies is still low. Furthermore, there are $40.8 \%$ of students who choose number 3 , meaning that the ability of lecturers in using various communication technologies is still moderate. Then, there are $48.3 \%$ of students who choose number 4 , meaning that the ability of lecturers in using various communication technologies is high. And lastly, there are $8.8 \%$ of students who choose the number 5 , meaning that the ability of lecturers in using a variety of communication technology is very high. So from the results of the analysis can be concluded that most students judge that the ability of lecturers in using various communication technology has been seen from the percentage of students who chose the number 4 , namely $48.3 \%$ students.

Discussion

The data below is processed using simple tabulation techniques and the data already collected is presented in the following table Form:

Tabulation of Data on Student Perception to Lecturer Professionalism in Conducting Online Based Learning 


\begin{tabular}{|c|c|c|c|}
\hline No & Aspects & Score & Category \\
\hline 1. & English Ability & 2,8 & Medium \\
\hline 2. & Teaching & 3,1 & High \\
\hline 3. & Insights & 2,9 & Medium \\
\hline 4. & Timeliness & 3,3 & High \\
\hline 5. & $\begin{array}{l}\text { Mastery of online } \\
\text { learning apps }\end{array}$ & 3,6 & High \\
\hline & Average & 3,14 & High \\
\hline
\end{tabular}

The table above shows that the average score given by the student to the lecturer is 3.14 . This means that, based on student perception, professionalism faculty PBI IAIN Parepare categorized as high.

a. English Ability

Theoretically, English proficiency is categorized into fluency and accuracy. Fluency, or the smooth use of language in communicating include listening, speaking, reading, and writing skills. Accuracy, which is accurate using the rules of the linguistic, includes Mastery of vocabulary, grammar and pronunciation. According to the table above the English proficiency of lecturers of English Education program IAIN Parepare entered into medium category. Based on the observation result the lecturers are not fully use English in the process of learning and teaching in consideration students will be difficult to understand the materials.

b. Online Teaching Skills

In the table above, it can be seen that teaching skills are classified in high category. This result shows the lecturers of English education program has a good qualification in teaching especially in Online teaching. Even the result of this point is a high category but in a further observation the researcher gained that most lecturers give assignments without giving explanation in depth. So students are confused to work on a given task.

\section{c. Insights}

Insight is also categorized as medium. This assessment may indicate that English education lecturers in IAIN Parepare are open enough to new information and that is positive for the development of this department.

d.Timeliness

Timeliness is a very important aspect for a lecturer. In the table above, it can be seen that these points are entered into the high category. This means that the PBI faculty of IAIN Parepare has a good commitment to carry out its duties as a teacher.

e. Mastery of Online Learning Apps

This skill also belongs to a high category. Based on the observation result, PBI IAIN Parepare lecturers can use the Learning app well and take advantage of the various features in the application as well. This is what leads students to give high value to this point.

\section{Conclusion}

From the Results of the discussion above, can be concluded a few things as follows:

With an average score of 3 it can be concluded that the English education lecturers of IAIN Parepare are rated to have high professionalism.

While there are still some relatively low points, It does not seem to apply to all lectures that have been observed in this study. 


\section{References}

Harmer, Jeremy, 2007, The Practice of English Language Teaching (Fourth Edition), Pearson Education Limited, England.

Siagian, Sondang P., 2009, Kiat Meningkatkan Produktivitas Kerja, Rineka Cipta, Yogyakarta.

Prasetyo, Bambang dan Jannah, Lina Miftahul, 2012, Metode Penelitian Kuantitatif: Teori dan Aplikasi, Rajawali Pers, Jakarta.

Jonner, S. (2014). Persepsi Mahasiswa Terhadap Profesionalisme Dosen Program Studi Pendidikan Bahasa Inggris FKIP, Jurnal Ilmiah, 14(4).

Azhar, S. (2013). Profesionalisme Guru Dalam Pembelajaran. Jurnal Adabiyah, 13(2), 203-213.

Simbolon, M. (2007). Persepsi dan Kepribadian. Jurnal ekonomis, 1(1), 52-66.

Arikunto, Suharsimi et.al, (2009), Evaluasi Program Pendidikan (Edisi Kedua), Bumi Aksara, Jakarta. 